\title{
ALOMETRIC RELATIONSHIPS BETWEEN VOLUME TO SURFACE RATIO, GENERATION TIME, MASS-CORRECTED METABOLIC RATE AND LIFESPAN METABOLIC POTENTIAL OF LIVING CELLS IN MODEL FOR SWITCH OF GENE PROGRAMS FROM GROWTH TO DIFFERENTIATION AND APPOPTOSIS
}

\author{
A. Atanasov ${ }^{*}$, Maria M. K. Ignatova ${ }^{2}$ \\ ${ }^{1}$ Faculty of Medicine, Department of Physics and Biophysics, Trakia University, Stara Zagora, \\ Bulgaria \\ ${ }^{2}$ Medical Student, Faculty of Medicine, Trakia University, Stara Zagora, Bulgaria
}

\begin{abstract}
The works of the other scientists have showed that the change of the size and form of the cells can leads to change of their mass-energy and spatial-time characteristics, as well as to switch gene programs of the cells from growth to differentiation and to apoptosis. In this direction the idea for control of metabolic, spatial-time and signaling pathways in cells via manipulation of volume to surface ratio (namely shape and size of the cells) is developed in manuscript. The base for such manipulation and control on cellular functions is existence of linear relationship between the volume to surface ratio $(\mathrm{V} / \mathrm{S}, \mathrm{m})$ and generation time $\left(\mathrm{T}_{\mathrm{gt}}, \mathrm{s}\right)$ in unicellular organisms $(\mathrm{n}=18): \mathrm{V} / \mathrm{S}=\mathrm{a}_{\mathrm{vst}} \mathrm{T}_{\mathrm{gt}}{ }^{1.0975}\left(\mathrm{R}^{2}=0.815\right)$ and existence of nearly to inversely-linear relationship between the volume to surface ratio and mass-corrected metabolic rate $\left(\mathrm{P}^{*}=\mathrm{P} / \mathrm{M}, \mathrm{J} / \mathrm{s} . \mathrm{kg}\right)$ in unicellular organisms $(\mathrm{n}=18): \mathrm{V} / \mathrm{S}=\mathrm{b}_{\mathrm{vsm}} / \mathrm{P}^{* 0.8796}\left(\mathrm{R}^{2}=0.70\right)$. The found relationships showed that the metabolic rate and the generation time of the cells are strongly connected to their volume to surface ratio. Thus, the manipulation of volume to surface ratio leads to changes of the basal metabolic rate and generation time of the cells, and this can switch their gene programs from growth to differentiation and to apoptosis. The proposed model is based on universality of the alometric relationships simultaneously for unicellular organisms (bacteria, protozoa) and for soma cells of the multicellular organisms.
\end{abstract}

Key words: alometric, living cells, gene programs, metabolism, generation time.

\section{INTRODUCTION}

The works of the other scientists have showed that the change of size and form of the cell can leads to change of their mass-energy, spatialtime and informational characteristics (gene programs). The idea for control of metabolic, spatial-time and signaling pathways in cells via manipulation of size and shape of cells is developed in others theoretical and experimental works. On prokaryotic bacterial cells Donachie and Begg (1) experimentally demonstrated an existence of connection between form and size of the cells and their gene programs . On Escherichia coli mutants the authors have showed that transition from rod-shape to spherical and ellipsoidal-shape

\footnotetext{
* Correspondence to: Atanas Todorov Atanasov, Faculty of Medicine, Department of Physics and Biophysics, Thracian University, 11 Armeiska Str., 6000 Stara Zagora, Bulgaria, E-mail: atanastod@abv.bg
}

form of cells lead to change of their generation time and growth rate. However, the authors do not fully explain the intimate mechanism. A similar connection between cell size, growth rate and generation time in Escherichia coli and Azotobacter agilis is demonstrated by experiments of Harvey, Marr and Painter (2). On eukaryotic cell (capillary endothelial cells) Ingber and co-workers $(3,4)$ showed that the change of cell shape with same volume can switch gene programs of cells from growth to differentiation and apoptosis -Figure 1. Ingber and Folkman (4) have showed that cell shape is the most critical determination of cell function, at least in the present of optimal growth factors and high extracellular matrix binding. Thus, cell shape per se appears to govern how individual cells will respond to chemical signals in their microenvironment, as first proposed by Folkman and Moscona (5). Ingber and Jamieson have proposed that this 
ATANASOV A., et al.

mechanism for establishing local growth differentials may play a critical role in morphogenesis in all developing systems (6). The idea for link between cell size, genome size (noncoding DNA) and metabolic rate in cells is developed by Kosłowski, Konarzewski and Gawelczyk (7). The authors proposed that accumulation of noncoding DNA may be under strong selection toward increase of body size, accompanied by low metabolic costs. Thus, genome size directly affects cell size and indirectly affects specific metabolic rate. Indeed, Atanasov and Petrova-Tacheva (8) have showed strong alometric connection between genome size (C-value) of wide

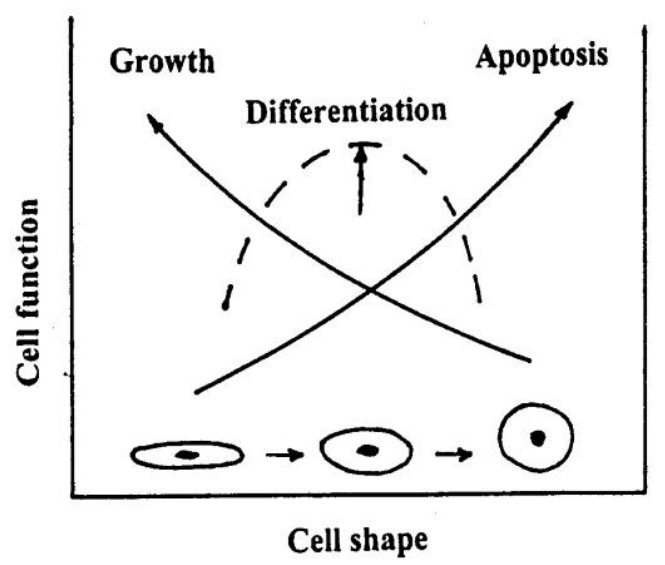

spectrum of cells and organisms and their metabolic characteristics. On multicellular level (colonial ascidians) a link between colonial size and metabolic rate of colony is clearly demonstrated by Nakaya, Saito and Motokawa (9). By manipulation of colonial size authors have showed that the metabolic rate and colony size followed the threequarters power law. Meyers, Craig and Odde (10) in single theoretical model have showed on spherical cells that increasing of cell radius leads to decreases of global phosphorylation on cellular level and phosphorylated form of the substrates (Figure 1).

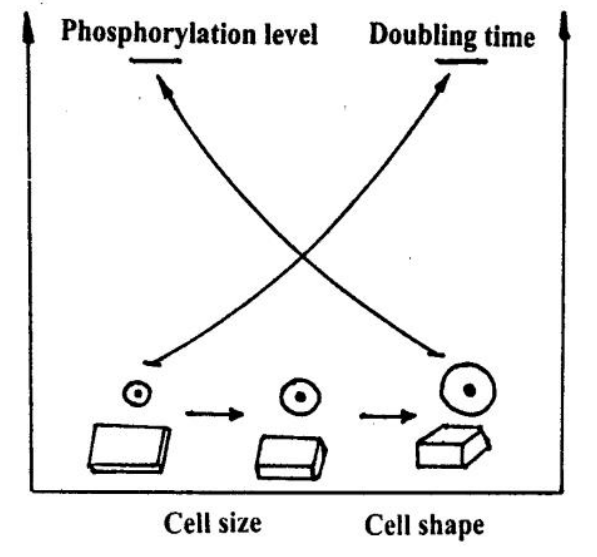

Figure 1. Diagrams of connection between cell shape and cell function accordingly Ingber (3) and Nakaya et al.(9), and phosphorylation level and doubling time in cells with other shape and size, accordingly Meyers et al. (10).

The same authors have showed that transition from cuboidal form to sheet-like form of the cells (with same volume) leads to increases of global phosphorylation levels in the cells and in the cell substrates.

What is the mechanism by which the cell shape and size exerts its effect on cell function? Clearly, the full answer is unknown. In this study we develop the hypothesis, the manipulation of the cell shape and size leads to manipulation of the cell volume to surface ratio and in result - the volume to surface ratio acts on integral cell functions (metabolic rate and generation time) and these actions switch gene programs of the cells from growth to differentiation and to apoptosis. The support of this hypothesis appears some previous works of Atanasov (11- 15) in which the author has showed that in unicellular organisms and in multicellular Poikilotherms, Mammals and Aves, the volume to surface ratio $(\mathrm{V} / \mathrm{S}, \mathrm{m})$ of organisms is connected to the generation time $\left(\mathrm{T}_{\mathrm{g}}, \mathrm{s}\right)$ (or lifespan $\mathrm{T}_{\mathrm{ls}}, \mathrm{s}$ ), and mass-corrected metabolic rate $\left(\mathrm{P}^{*}=\mathrm{P} / \mathrm{M}, \mathrm{J} / \mathrm{s} . \mathrm{kg}\right)$ by the equations:

$$
\begin{aligned}
& \mathrm{V} / \mathrm{S}=\mathrm{a}_{\mathrm{vss}} \times \mathrm{T}_{\mathrm{gt}}=\mathrm{a}_{\mathrm{vst}} \times \mathrm{T}_{\mathrm{ls}} \\
& \mathrm{V} / \mathrm{S}=\mathrm{b}_{\mathrm{vsm}} / \mathrm{P}^{*}
\end{aligned}
$$

where the coefficients $a_{v s t}$ and $b_{v s m}$ are relatively constant parameters for unicellular and multicellular organisms. In Eq. 2 the masscorrected metabolic rate $\mathrm{P}^{*}(\mathrm{~J} / \mathrm{s} . \mathrm{kg})$ is given as ratio between basal (or growing metabolic rate) $\mathrm{P}(\mathrm{J} / \mathrm{s})$ and the body mass $\mathrm{M}(\mathrm{kg})$ of organism i.e. $\mathrm{P}^{*}=\mathrm{P} / \mathrm{M}$.

The product between the mass-corrected metabolic rate $\mathrm{P}^{*}(\mathrm{~J} / \mathrm{s} . \mathrm{kg})$ and the generation time $\mathrm{T}_{\mathrm{gt}}(\mathrm{s})$ or lifespan $\mathrm{T}_{\mathrm{ls}}(\mathrm{s})$ gives the 'lifespan metabolic potential' $A_{\mathrm{ls}}(\mathrm{J} / \mathrm{kg})$ of the cells and organisms i.e.:

$\mathrm{P}^{*} \times \mathrm{T}_{\mathrm{gt}}=\mathrm{P}^{*} \times \mathrm{T}_{1 \mathrm{~s}}=\mathrm{A}_{\mathrm{ls}}$

The term 'metabolic potential' is defined firstly from Rübner (16) as a universal metabolic constant (Rubner's constant). Later, in scientific literature the Rubner's constant is named 'lifespan metabolic potential'. Lifespan metabolic potential expresses the mean value of total metabolic energy per lifespan exhausted from $1 \mathrm{~kg}$ body mass of the given organism, per lifespan and can be received as 
ratio between the total metabolic energy per lifespan and the body mass of the organism:

$$
\mathrm{A}_{\mathrm{ls}}=\left(\mathrm{P} \times \mathrm{T}_{\mathrm{gt}}\right) / \mathrm{M}=\left(\mathrm{P} \times \mathrm{T}_{\mathrm{ls}}\right) / \mathrm{M},(\mathrm{J} / \mathrm{kg}) \quad(4),
$$

From Unicellular organisms to Poikilotherms, Mammals and Aves the "lifespan metabolic potential' ranges about 4 orders of magnitude, from $1.0 \times 10^{7} \mathrm{~J} / \mathrm{kg}$ in Unicellular organisms to $1.0 \times 10^{11} \mathrm{~J} / \mathrm{kg}$ in Aves. It appears relatively constant parameter, giving in the mind that the body mass of the living organisms range 21 orders of magnitude, from $1.0 \times 10^{-17} \mathrm{~kg}$ in bacteria to $1.0 \times 10^{4} \mathrm{~kg}$ in big Mammals.

The aim of the study is: 1) to connect the Eq.1 and Eq.2 with experimental results about metabolism and generation time in unicellular organisms and 2) by these equations to explain the manipulation of signaling pathways in cells leading to switch of their gene programs from growth to differentiation and apoptosis.

\section{DATA AND METHODS}

The data for the cell mass, volume to surface ratio, metabolic rate and generation time in Unicellular prokaryotic and eukaryotic organisms are assembled from previous works of Atanasov (10-15), Holt (17) and Lee et al. (18), and are presented in Table 1.

The alometric relationships between volume/surface ratio, generation time and mass-corrected metabolic rate are calculated by statistical program 'STATISTICA'.

Table 1. Data for cell mass, volume to surface ratio, mass-corrected metabolic rate and generation time in prokaryotic and eukaryotic unicellular organisms

\begin{tabular}{|c|c|c|c|c|c|}
\hline $\begin{array}{l}\text { Living } \\
\text { organisms }\end{array}$ & $\begin{array}{l}\text { ll Mass Vo } \\
\text { M (kg) }\end{array}$ & $\begin{array}{l}\text { Volume/Surface } \\
\text { ratio } \\
\text { V/S (m) }\end{array}$ & $\begin{array}{l}\text { Generation } \\
\text { time } \\
\quad \mathbf{T}_{\mathrm{gt}}(\mathbf{s}) \\
\end{array}$ & $\begin{array}{c}\text { Mass-corrected } \\
\text { metabolic rate } \\
\text { P*= P/M (J/s.kg) }\end{array}$ & $\begin{array}{c}\text { Metabolic } \\
\text { potential } \\
\mathbf{A}_{\mathrm{ls}}=\mathbf{P} * \mathbf{T}_{\mathrm{gt}}(\mathrm{J} / \mathrm{kg})\end{array}$ \\
\hline \multicolumn{6}{|l|}{ Prokaryotes } \\
\hline 1.Hemophilus & $1.0 \times 10^{-17}$ & $4.12 \times 10^{-8}$ & $1.2 \times 10^{3}$ & $5.0 \times 10^{5}$ & $6.0 \times 10^{8}$ \\
\hline 2.Diplococcus & $3.8 \times 10^{-16}$ & $1.37 \times 10^{-7}$ & $1.52 \times 10^{3}$ & $1.335 \times 10^{5}$ & $2.03 \times 10^{8}$ \\
\hline 3. Escherichia & $3.9 \times 10^{-16}$ & $1.38 \times 10^{-7}$ & $1.8 \times 10^{3}$ & $1.301 \times 10^{5}$ & $2.34 \times 10^{8}$ \\
\hline 4.Nitrobacter & $5.0 \times 10^{-16}$ & $1.5 \times 10^{-7}$ & $3.6 \times 10^{3}$ & $1.2 \times 10^{5}$ & $4.32 \times 10^{8}$ \\
\hline 5.Shigella & $7.1 \times 10^{-16}$ & $1.68 \times 10^{-7}$ & $1.38 \times 10^{3}$ & $1.12 \times 10^{5}$ & $1.545 \times 10^{8}$ \\
\hline 6.Staphylococcus & $7.8 \times 10^{-16}$ & $3.7 \times 10^{-7}$ & $3.6 \times 10^{3}$ & $9.0 \times 10^{4}$ & $3.96 \times 10^{8}$ \\
\hline 7.Azotobacter & $2 \times 10^{-15}$ & $2.365 \times 10^{-7}$ & $3.6 \times 10^{3}$ & $2.79 \times 10^{4}$ & $1.00 \times 10^{8}$ \\
\hline 8. Bacillus & $4.3 \times 10^{-15}$ & $3.05 \times 10^{-7}$ & $3.0 \times 10^{3}$ & $7.1 \times 10^{4}$ & $2.13 \times 10^{8}$ \\
\hline \multicolumn{6}{|l|}{ Eukaryotes } \\
\hline 9.Saccharomyces & $2 \times 10^{-14}$ & $5.05 \times 10^{-7}$ & $7.2 \times 10^{3}$ & $4.5 \times 10^{3}$ & $2.88 \times 10^{7}$ \\
\hline 10.Flagellata & $1 \times 10^{-13}$ & $8.6 \times 10^{-7}$ & $3.5 \times 10^{4}$ & $3.47 \times 10^{3}$ & $1.5 \times 10^{8}$ \\
\hline 11.Mastogophora & $1 \times 10^{-13}$ & $8.6 \times 10^{-7}$ & $3.5 \times 10^{4}$ & $3.47 \times 10^{3}$ & $1.5 \times 10^{8}$ \\
\hline 12. Euglena & $8 \times 10^{-12}$ & $3.65 \times 10^{-6}$ & $3.45 \times 10^{4}$ & $4.0 \times 10^{3}$ & $3.7 \times 10^{8}$ \\
\hline 13.Chlamydomonas & $4 \times 10^{-12}$ & $2.9 \times 10^{-6}$ & $4.0 \times 10^{4}$ & $1.273 \times 10^{3}$ & $7.33 \times 10^{7}$ \\
\hline 14.Tetrahymena & $2 \times 10^{-11}$ & $4.94 \times 10^{-6}$ & $4.5 \times 10^{4}$ & $6.0 \times 10^{3}$ & $1.58 \times 10^{8}$ \\
\hline 15.Paramecium & $4 \times 10^{-10}$ & $1.33 \times 10^{-5}$ & $8.64 \times 10^{4}$ & $4.0 \times 10^{3}$ & $5.83 \times 10^{8}$ \\
\hline 16.Pelomyxa & $1 \times 10^{-9}$ & $1.8 \times 10^{-5}$ & $12.96 \times 10^{4}$ & $3.0 \times 10^{3}$ & $3.9 \times 10^{8}$ \\
\hline 17. Amoeba & $2 \times 10^{-8}$ & $4.83 \times 10^{-5}$ & $17.28 \times 10^{4}$ & $2.89 \times 10^{3}$ & $5.0 \times 10^{8}$ \\
\hline 18.Stentor & $8 \times 10^{-8}$ & $7.6 \times 10^{-5}$ & $21.00 \times 10^{4}$ & $1.07 \times 10^{3}$ & $1.85 \times 10^{8}$ \\
\hline
\end{tabular}

RESULTS AND DISSCUSSION

I. Linear relationships between volume to surface ratio and generation time, and inversely relationships between volume to surface ratio and mass-corrected metabolic rate in unicellular organisms.

Comparative relationship between volume to surface ratio, mass-corrected metabolic rate, generation time and lifespan metabolic potential for prokaryotic and eukaryotic unicellular organisms is present on Figure 2 in log-log plots. The generation time $\left(\mathrm{T}_{\mathrm{gt}}\right)$ changes linearly as a function of volume to surface ratio. The curve of mass-corrected metabolic rate $\left(\mathrm{P}^{*}\right)$ as a function of volume to surface ratio has different slopes for prokaryotic and eukaryotic cells. Lifespan metabolic potential $\left(\mathrm{A}_{\mathrm{ls}}\right)$ presented by horizontal line on the Figure 2 don't depend on volume to surface ratio of the cells. In additional, on Figure 3, Figure 5 and Figure 6 separately are present the allometric relationships between $\mathrm{V} / \mathrm{S}$ rtaio, $\mathrm{T}_{\mathrm{gt}}, \mathrm{P}^{*}$ and $\mathrm{A}_{\mathrm{ls}}$. 


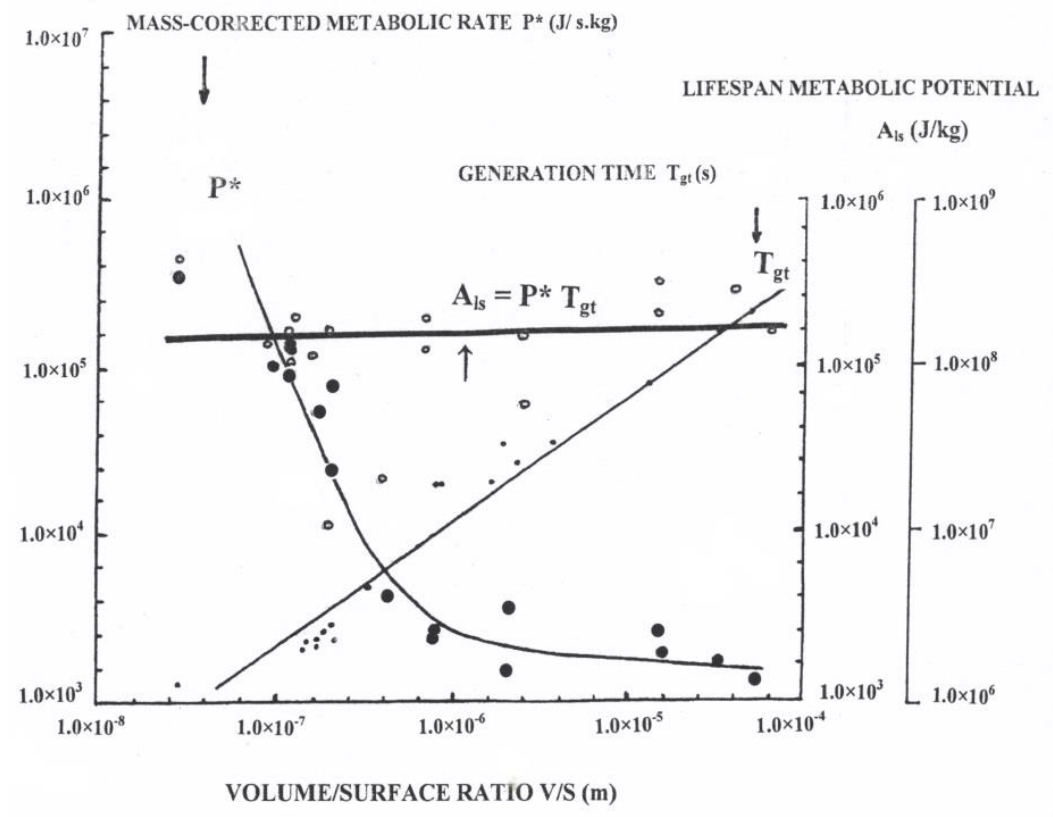

Figure 2. Mass-corrected metabolic rate (curve $\mathrm{P}^{*}$ ), generation time (line $\mathrm{T}_{\mathrm{gt}}$ ) and lifespan metabolic potential (horizontal line $\mathrm{A}_{\mathrm{ls}}$ ) of cells (prokaryotes and eukaryotes) as a function of volume to surface ratio in log-log plots.

Alometric analysis has shown that a nearly to linear relationships between the volume to surface ratio $\mathrm{V} / \mathrm{S}(\mathrm{m})$ and the generation time $\mathrm{T}_{\mathrm{gt}}$ (s) (or lifespan $\mathrm{T}_{\mathrm{ls}}$ ) of 18 unicellular organisms (8 prokaryotes and 10 eukaryotes) in log-log plots holds (Figure 3):
$\mathrm{V} / \mathrm{S}=\mathrm{a}_{\mathrm{vst}} \times \mathrm{T}_{\mathrm{gt}}^{1.0975}$ with $\mathrm{R}^{2}=0.815$

where $a_{\text {vst }}=3.475 \times 10^{-11}(\mathrm{~m} / \mathrm{s})$ appears relatively constant parameter.

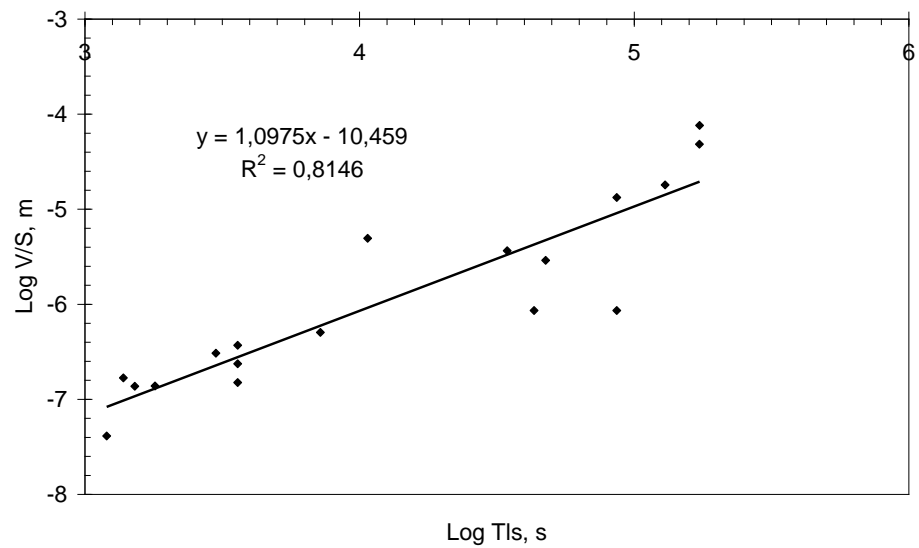

Figure 3. Volume to surface ratio as a function of generation time $\mathrm{T}_{\mathrm{gt}}$ (or lifespan $\mathrm{T}_{\mathrm{ls}}$ ) of the cells.

The biological sense of parameter $a_{v s t}$ is a binary. This speed is near to linear speed of speed of growth of volume to surface ratio, cell growth (see Figure 4 and Table 2). during growth and multiplication of cells by

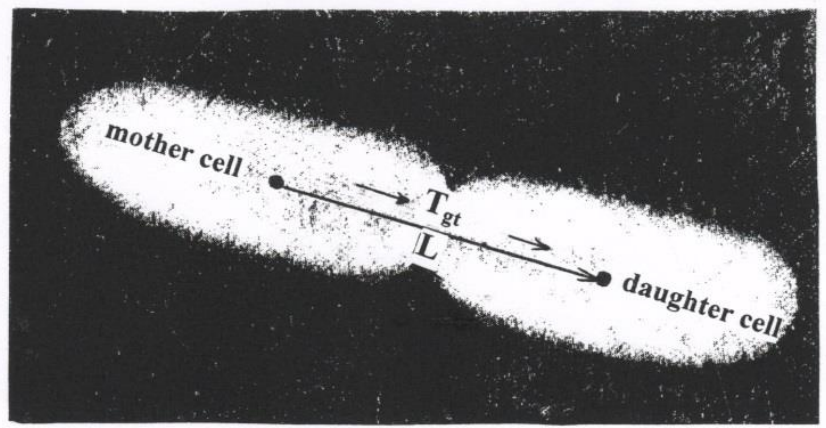

Figure 4. The biological sense of $\mathrm{a}_{\mathrm{vst}}$ as linear speed of cell growth, during multiplication of cells by binary. Legend: $\mathrm{L}$ - is a distance between the centers of the mother and daughter cells, $\mathrm{T}_{\mathrm{gt}}-$ is a generation and the linear speed of cell growth corresponds to $\mathrm{L} / \mathrm{T}_{\mathrm{gt}}$ ratio or $\mathrm{V} /\left(\mathrm{S} \mathrm{T}_{\mathrm{gt}}\right)$ ratio. 
Allometric analysis has shown that a inversely linear relationships between the volume to surface ratio $\mathrm{V} / \mathrm{S}(\mathrm{m})$ and the mass-corrected metabolic rate $\mathrm{P}^{*}=$ $\mathrm{P} / \mathrm{M}(\mathrm{J} / \mathrm{s} . \mathrm{kg})$ of 18 unicellular organisms
ATANASOV A., et al.

(8 prokaryotes and 10 eukaryotes) in

log-log plots holds (Figure 5):

$\mathrm{V} / \mathrm{S}=\mathrm{b}_{\mathrm{vsm}} / \mathrm{P}^{* 0.8796}$ with $\mathrm{R}^{2}=0.70$

where $b_{v s m}=5.653 \times 10^{-3}(\mathrm{~J} \cdot \mathrm{m} / \mathrm{kg} \cdot \mathrm{s})$ are parameters with relatively constant values.

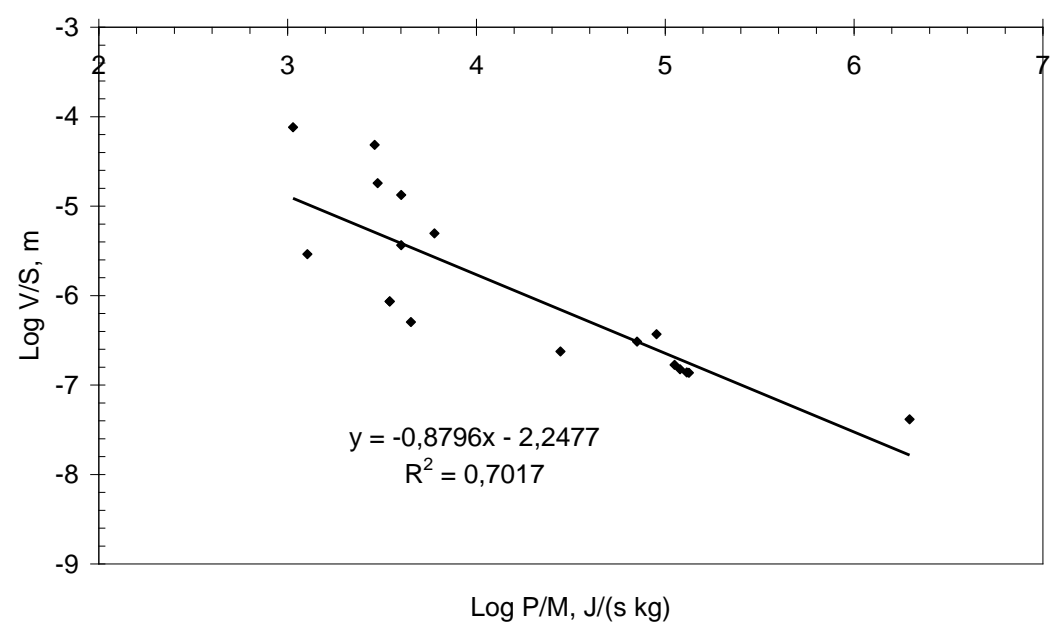

Figure 5. Volume to surface ratio as a function of mass-corrected metabolic rate $\mathrm{P}^{*}=\mathrm{P} / \mathrm{M}$ of cells (prokaryotes and eukaryotes).

Allometric analysis has shown that 'lifespan metabolic potential' $\mathrm{A}_{\mathrm{ss}}$ don't depend on volume to surface ratio V/S (m) and change in narrow window (from $2.88 \times 10^{7} \mathrm{~J} / \mathrm{kg}$ to $6.0 \times 10^{8} \mathrm{~J} / \mathrm{kg}$ ) for full diapason of volume to surface ratio (from $4 \times 10^{-8} \mathrm{~m}$ to $7.6 \times 10^{-5} \mathrm{~m}$ )- (Figure 6). The correlation coefficient $\mathrm{R}^{2}$ $=0.0015$ between $A_{\mathrm{ls}}$ and V/S ratio is very near to zero.

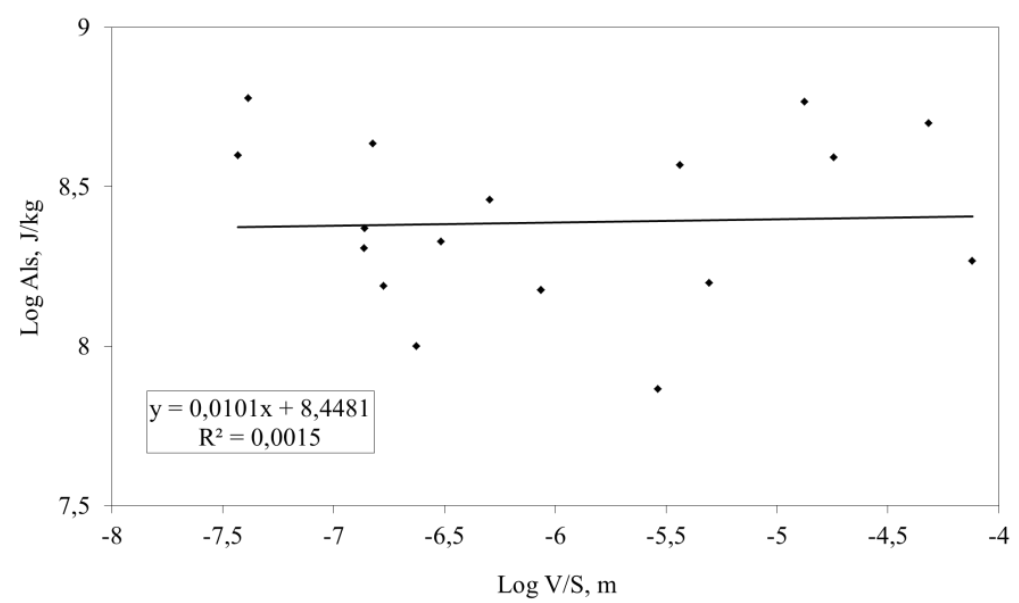

Figure 6. Lifespan metabolic potential as a function of volume to surface ratio V/S of the cells (prokaryotes and eukaryotes).

The calculated on Table 2 linear speed of cell growth $\left(\mathrm{v}_{\text {cell }}\right)$ falls in diapason from $1.0 \times 10^{-8}$ $\mathrm{m} / \mathrm{s}$ to $1.0 \times 10^{-11} \mathrm{~m} / \mathrm{s}$ and overlaps with diapason of values for the constant parameter $\mathrm{a}_{\mathrm{vst}}=$ V/S.T $\mathrm{gt}_{\mathrm{gt}}$ calculated from Eq.5 (see Table 2).

The parameter $b_{v s m}$ can be made as a product between mass-corrected metabolic rate $\mathrm{P}^{*}$ and volume to surface ratio $\mathrm{V} / \mathrm{S}$ :

$\mathrm{b}_{\mathrm{vsm}}=\mathrm{P}^{*}(\mathrm{~V} / \mathrm{S})$

The biological sense of coefficient $b_{v s m}$ can regards as a ratio between basal metabolic rate of cells $\mathrm{P}(\mathrm{J} / \mathrm{s})$, cell surface $\mathrm{S}\left(\mathrm{m}^{2}\right)$ and cell density $\left.\rho=1100 \mathrm{~kg} / \mathrm{m}^{3}\right)$ :

$$
\mathrm{b}_{\mathrm{vsm}}=\mathrm{P} / \mathrm{S} \rho
$$

The values of coefficient $b_{v s m}$ calculated by data on Table 3 changes 2 orders of magnitude from $1.0 \times 10^{-1}$ to $1.0 \times 10^{-3}(\mathrm{~J} \cdot \mathrm{m} / \mathrm{kg} \cdot \mathrm{s})$. Thus, the coefficient $b_{v s m}$ appears a relatively constant parameter, giving in the mind 21 orders of magnitude difference between the cell mass from bacteria to amoeba. 
ATANASOV A., et al.

Table 2. Data for body mass, minimum and maximum linear size and generation time in prokaryotic and eukaryotic unicellular organisms (data by Holt (17), Lee et al. (18) and calculated speeds of linear growth presented by linear size and volume to surface ratio of the cells

\begin{tabular}{|c|c|c|c|c|}
\hline $\begin{array}{l}\text { Unicellular } \\
\text { organisms }\end{array}$ & $\begin{array}{l}\text { Body mass } \\
\mathrm{M}(\mathrm{kg})\end{array}$ & $\begin{array}{l}\text { Min-max size } \\
L(m)\end{array}$ & $\begin{array}{l}\text { Generation time } \\
\mathrm{T}_{\mathrm{gt}}(\min , \mathrm{h})\end{array}$ & $\begin{array}{c}\text { Speed of growth } \\
v_{\text {cell }}=\mathrm{L} / \mathrm{T}_{\mathrm{gt}}=\mathrm{V} / \mathrm{S} \cdot \mathrm{T}_{\mathrm{gt}}\end{array}$ \\
\hline \multicolumn{5}{|c|}{ PROKARYOTES (bold data gives all diapason) } \\
\hline Mycoplasmatales $2 \times 10^{-1}$ & $-17=2.0 \times 10^{-16}$ & $0.1-0.6 \times 10^{-6}$ & 20min-2.5h & $1.1 \times 10^{-11}-5 \times 10^{-10}$ \\
\hline Mycoplasma arthritidis & $4 \times 10^{-17}$ & $0.2-0.5$ & $20 \mathrm{~min}-2.5 \mathrm{~h}$ & $2.2 \times 10^{-11}-4.1 \times 10^{-10}$ \\
\hline Mycoplasma mycoides & $5 \times 10^{-17}$ & $0.25-0.33$ & $20 \mathrm{~min}-2.5 \mathrm{~h}$ & $2.8 \times 10^{-11}-2.75 \times 10^{-10}$ \\
\hline Rickettsiales $\quad 2 \times 10^{-1}$ & $-17-1.0 \times 10^{-15}$ & $0.1-2.0 \times 10^{-6}$ & $20 \mathrm{~min}-2.5 \mathrm{~h}$ & $1.1 \times 10^{-11}-2.75 \times 10^{-10}$ \\
\hline Rickettsii (Brucella) $\quad(0.2$ & $2-1.0) \times 10^{-16}$ & $0.1-0.4$ & 20min-1.0h & $2.8 \times 10^{-11}-3.3 \times 10^{-10}$ \\
\hline Small Chlamydii & $3.0 \times 10^{-17}$ & $0.2-0.5$ & $20 \mathrm{~min}-2.0 \mathrm{~h}$ & $2.6 \times 10^{-11}-4.1 \times 10^{-10}$ \\
\hline Haemobatonella muris & $2 \times 10^{-16}$ & $0.1 \times 0.3-0.7$ & $20 \mathrm{~min}-5.0 \mathrm{~h}$ & $3.3 \times 10^{-11}-5.8 \times 10^{-10}$ \\
\hline Bdellovibrio bacteriovorus & s $2.5 \times 10^{-16}$ & $0.3 \times 1.0$ & $20 \mathrm{~min}-10 \mathrm{~h}$ & $3.3 \times 10^{-11}-8.3 \times 10^{-10}$ \\
\hline EUKARYOTES $2 \times 10^{-14}$ & $4-1.0 \times 10^{-8}$ & $5 \times 10^{-6}-1.0 \times 10^{-3}$ & $3 \times 10^{3}-2.0 \times 10^{5}$ & $1.0 \times 10^{-10}-1.0 \times 10^{-8}$ \\
\hline Saccharomyces & $2.0 \times 10^{-14}$ & $5.0 \times 10^{-6}$ & $(3.6-7.2) \times 10^{3} \mathrm{~s}$ & $(1.39-0.7) \times 10^{-10}$ \\
\hline Euglena & $8.0 \times 10^{-12}$ & $8.0 \times 10^{-6}$ & $3.45 \times 10^{4} \mathrm{~s}$ & $2.32 \times 10^{-10}$ \\
\hline Tetrahymena & $2.0 \times 10^{-11}$ & $1.0 \times 10^{-5}$ & $(2.16-2.88) \times 10^{4} \mathrm{~s}$ & $(3.5-4.6) \times 10^{-10}$ \\
\hline Paramecium & $4.0 \times 10^{-10}$ & $1.0 \times 10^{-4}$ & $8.64 \times 10^{4} \mathrm{~s}$ & $1.157 \times 10^{-9}$ \\
\hline Pelomyxa & $1.0 \times 10^{-9}$ & $1.0 \times 10^{-3}$ & $12.96 \times 10^{4} \mathrm{~s}$ & $7.716 \times 10^{-8}$ \\
\hline Amoeba & $2.0 \times 10^{-8}$ & $2.0 \times 10^{-3}$ & $17.28 \times 10^{4} \mathrm{~s}$ & $1.157 \times 10^{-8}$ \\
\hline
\end{tabular}

Table 3. Cell mass, cell surface, metabolic rate, (metabolic rate)/surface ratio, and parameter $b_{v s m}$ in prokaryotic and eukaryotic cells (by Atanasov 11, 12, 13, 14, 15).

\begin{tabular}{|c|c|c|c|c|c|}
\hline $\begin{array}{l}\text { Living } \\
\text { organisms }\end{array}$ & $M(\mathrm{~kg})$ & $\begin{array}{l}\text { Surface } \\
\text { area } \\
\mathbf{S}\left(\mathbf{m}^{2}\right)\end{array}$ & $\begin{array}{l}\text { Metabolic Met } \\
\text { rate } \\
\mathbf{P}(\mathrm{J} / \mathrm{s})\end{array}$ & $\begin{array}{l}\text { tabolic/Surface } \\
\text { ratio } \\
\text { P /S }\left(\mathbf{J} / \mathbf{m}^{2}\right)\end{array}$ & $\begin{array}{c}\mathbf{b}_{\mathrm{vsm}}=\mathrm{P} *(\mathrm{~V} / \mathrm{S}) \\
\mathbf{b}_{\mathrm{vsm}}=\mathrm{P} / \mathrm{S} \rho \\
(\mathrm{J} \cdot \mathrm{m} / \mathrm{kg} \cdot \mathbf{s})\end{array}$ \\
\hline \multicolumn{6}{|c|}{ Prokaryotes $\left(\rho=1100 \mathrm{~kg} / \mathrm{m}^{3}\right)$} \\
\hline 1.Hemophilus 1 & $1.0 \times 10^{-17}$ & $2.2 \times 10^{-13}$ & $1.97 \times 10^{-11}$ & $8.95 \times 10^{1}$ & $8.136 \times 10^{-2}$ \\
\hline 2.Diplococcus & $3.8 \times 10^{-16}$ & $2.37 \times 10^{-12}$ & $5.073 \times 10^{-11}$ & $2.004 \times 10^{1}$ & $1.822 \times 10^{-2}$ \\
\hline 3. Escherichia & $3.9 \times 10^{-16}$ & $2.57 \times 10^{-12}$ & $5.074 \times 10^{-11}$ & $1.974 \times 10^{1}$ & $1.795 \times 10^{-2}$ \\
\hline 5.Shigella & $7.1 \times 10^{-16}$ & $3.841 \times 10^{-12}$ & $7.952 \times 10^{-11}$ & $2.07 \times 10^{1}$ & $1.881 \times 10^{-2}$ \\
\hline 6.Staphylococcus & $7.8 \times 10^{-16}$ & $1.977 \times 10^{-12}$ & $8.85 \times 10^{-11}$ & $4.477 \times 10^{1}$ & $4.07 \times 10^{-2}$ \\
\hline 8. Bacillus & $4.3 \times 10^{-15}$ & $1.282 \times 10^{-11}$ & $3.053 \times 10^{-10}$ & $2.382 \times 10^{1}$ & $2.165 \times 10^{-2}$ \\
\hline \multicolumn{6}{|c|}{ Eukaryotes $\left(\rho=1100 \mathrm{~kg} / \mathrm{m}^{3}\right)$} \\
\hline 9.Saccharomyces & $2 \times 10^{-14}$ & $3.6 \times 10^{-11}$ & $8.0 \times 10^{-11}$ & 2.222 & $2.02 \times 10^{-3}$ \\
\hline 10.Flagellata & $1 \times 10^{-13}$ & $1.058 \times 10^{-10}$ & $3.47 \times 10^{-10}$ & 3.278 & $2.98 \times 10^{-3}$ \\
\hline 12. Euglena & $8 \times 10^{-12}$ & $2.0 \times 10^{-9}$ & $8.56 \times 10^{-8}$ & $4.29 \times 10^{1}$ & $3.90 \times 10^{-2}$ \\
\hline 13.Chlamydomonas & as $4 \times 10^{-12}$ & $1.25 \times 10^{-9}$ & $5.09 \times 10^{-9}$ & 4.062 & $3.692 \times 10^{-3}$ \\
\hline 14.Tetrahymena & $2 \times 10^{-11}$ & $3.68 \times 10^{-9}$ & $2.95 \times 10^{-7}$ & $8.015 \times 10^{1}$ & $7.286 \times 10^{-2}$ \\
\hline 15.Paramecium & $4 \times 10^{-10}$ & $2.7 \times 10^{-8}$ & $2.7 \times 10^{-6}$ & $9.878 \times 10^{1}$ & $8.98 \times 10^{-2}$ \\
\hline 16.Pelomyxa & $1 \times 10^{-9}$ & $5.1 \times 10^{-8}$ & $3.0 \times 10^{-6}$ & $5.94 \times 10^{1}$ & $5.40 \times 10^{-2}$ \\
\hline 17. Amoeba & $2 \times 10^{-8}$ & $3.79 \times 10^{-7}$ & $5.78 \times 10^{-5}$ & $1.525 \times 10^{2}$ & $1.396 \times 10^{-1}$ \\
\hline
\end{tabular}

From the ratio between Eq. 6 and Eq.5 we can express the metabolic potential of cells $\mathrm{A}_{\mathrm{ls}}$ : $\mathrm{V} / \mathrm{S}: \mathrm{V} / \mathrm{S}=\left(\mathrm{b}_{\mathrm{vsm}} / \mathrm{P}^{*}\right) /\left(\mathrm{a}_{\mathrm{vst}} \times \mathrm{T}_{\mathrm{gt}}\right)=\left(\mathrm{b}_{\mathrm{vsm}} / \mathrm{a}_{\mathrm{vst}}\right)$ $\left(1 / \mathrm{P}^{*} \mathrm{~T}_{\mathrm{gt}}\right)=1.0$

After reorganization above ratio we receive the equation for the metabolic potential $\mathrm{A}_{\mathrm{ls}}$ :

$$
\mathrm{A}_{\mathrm{ss}}=\mathrm{P}^{*} \times \mathrm{T}_{\mathrm{gt}}=\mathrm{b}_{\mathrm{vsm}} / \mathrm{a}_{\mathrm{vst}}
$$

In Eq.10 the lifespan metabolic potential $\mathrm{A}_{\mathrm{ls}}$ and consequently $b_{v s m}$, and $a_{v s t}$ are relatively constant parameters. From Eq.10 we can receive the inverse relationship between masscorrected metabolic rate $\left(\mathrm{P}^{*}\right)$ and the generation time $\left(\mathrm{T}_{\mathrm{gt}}\right)$ via lifespan metabolic potential:

$$
\mathrm{T}_{\mathrm{gt}}=\mathrm{A}_{\mathrm{ls}} / \mathrm{P}^{*}
$$

The Eq.11 shows that with increase of specific mass-corrected metabolism $\mathrm{P}^{*}$ the generation time $\mathrm{T}_{\mathrm{gt}}$ degreases, because of the metabolic potential $\mathrm{A}_{\mathrm{ls}}$ keep constantly.

Using Eq.10 we can express $b_{v s m}$ as a product between $\mathrm{a}_{\mathrm{vst}}(\mathrm{m} / \mathrm{s})$ and $\mathrm{A}_{\mathrm{ls}}(\mathrm{J} / \mathrm{kg})$ with dimension of $(\mathrm{J} / \mathrm{kg}) \times(\mathrm{m} / \mathrm{s})=(\mathrm{J} . \mathrm{m} / \mathrm{kg} . \mathrm{s})$ :

$\mathrm{b}_{\mathrm{vsm}}=\mathrm{a}_{\mathrm{vst}} \times \mathrm{A}_{\mathrm{ls}}=$ Const.

II. A model for manipulation of masscorrected metabolic rate and generation time in cells via manipulation of their volume to surface ratio. 
ATANASOV A., et al.

We propose that the linear relationship between volume to surface ratio and generation time, and inversely-linear relationship between volume to surface ratio and mass-corrected metabolic rate keep validity for all type of cells and cell lines i.e. prokaryotic, eukaryotic, soma and cultured cells. We propose that independently of volume to surface ratio of the cells the 'lifespan metabolic potential' keep constantly. The basic principle of manipulating experiments on cells can be formulated as, that the manipulation of any one: $\mathrm{V} / \mathrm{S}$ ratio, $\mathrm{P}^{*}$ and $\mathrm{T}_{\mathrm{gt}}$ always leads to change of others units, but keeps lifespan metabolic potential $\left(\mathrm{A}_{\mathrm{ls}}\right)$ constant (Scheme 1).

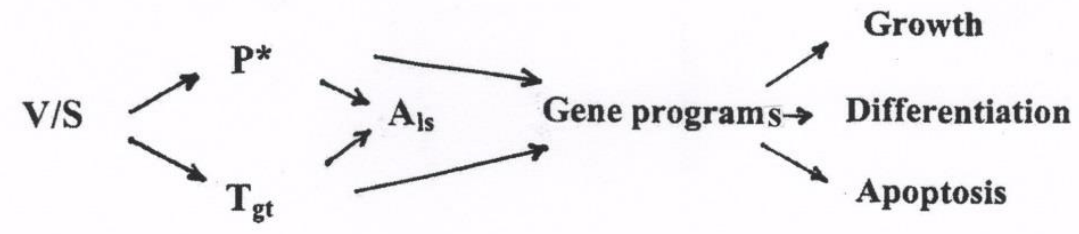

Scheme 1. Manipulation of volume to surface ratio leads to manipulation of mass-corrected metabolic rate and generation time so that to keeps metabolic potential $\left(\mathrm{A}_{\mathrm{ls}}\right)$ as a constant. This leads to switch of gene programs from growth to differentiation and apoptosis.

The necessary to keeps the metabolic potential $\left(\mathrm{A}_{\mathrm{ls}}\right)$ as constant parameter leads to necessary to switching gene programs from growth to differentiation and apoptosis. For given gene program the mass-corrected metabolic rate $\left(\mathrm{P}^{*}\right)$ and generation time $\left(\mathrm{T}_{\mathrm{gt}}\right)$ change so that 'lifespan metabolic potential' keep constantly i.e. $\mathrm{A}_{\mathrm{s}}$ (growth) $\approx \mathrm{A}_{\mathrm{ls}}$ (differentiation) $\approx$ $\mathrm{A}_{\mathrm{ls}}$ (apoptosis) $\approx \mathrm{P}^{*} \times \mathrm{T}_{\mathrm{gt}}$. The manipulating experiments can be explained by Figure 7.

Accordingly Figure 7 the principles of manipulating experiments can be formulated as followed:

1. The manipulating of gene programs of the cells may realize by manipulation of one or all units: $\mathrm{V} / \mathrm{S}$ ratio, $\mathrm{P}^{*}$ and $\mathrm{T}_{\mathrm{gt}}$ or $\mathrm{T}_{\mathrm{ls}}$.

2. The change of $\mathrm{V} / \mathrm{S}$ ratio, $\mathrm{P}^{*}, \mathrm{~T}_{\mathrm{gt}}$ or $\mathrm{T}_{\mathrm{ls}}$ in 'normal' physiological diapason of values for given type of cells leads to switching of gene programs from growth to differentiation. For low values of V/S ratio the cells shave highest $\mathrm{P}^{*}$ and lowest $\mathrm{T}_{\mathrm{gt}}$. Under these extreme physiological conditions the gene programs switch to 'grow regime' and utilize the energy for short time during the cells growth. For middle values of V/S ratio the cells have middle metabolic rate $\mathrm{P}^{*}$ and middle generation time (lifespan) $\mathrm{T}_{\mathrm{gt}}$. These physiological conditions are sufficient for differentiation, but don't sufficient for growth of the cells. In this case the gene programs switch to differentiation.

3. The changes of $\mathrm{V} / \mathrm{S}$ ratio, $\mathrm{P}^{*}, \mathrm{~T}_{\mathrm{gt}}$ or $\mathrm{T}_{\mathrm{ls}}$ out of 'normal' physiological diapason of values leads to switching of genetic programs to apoptosis. For high V/S ratio the cells have lowest metabolic rate $\mathrm{P}^{*}$ for highest $\mathrm{T}_{\mathrm{gt}}$ and the cells don't grow and don't differentiate because of the low level of metabolic energy. The gene programs switch to apoptosis.

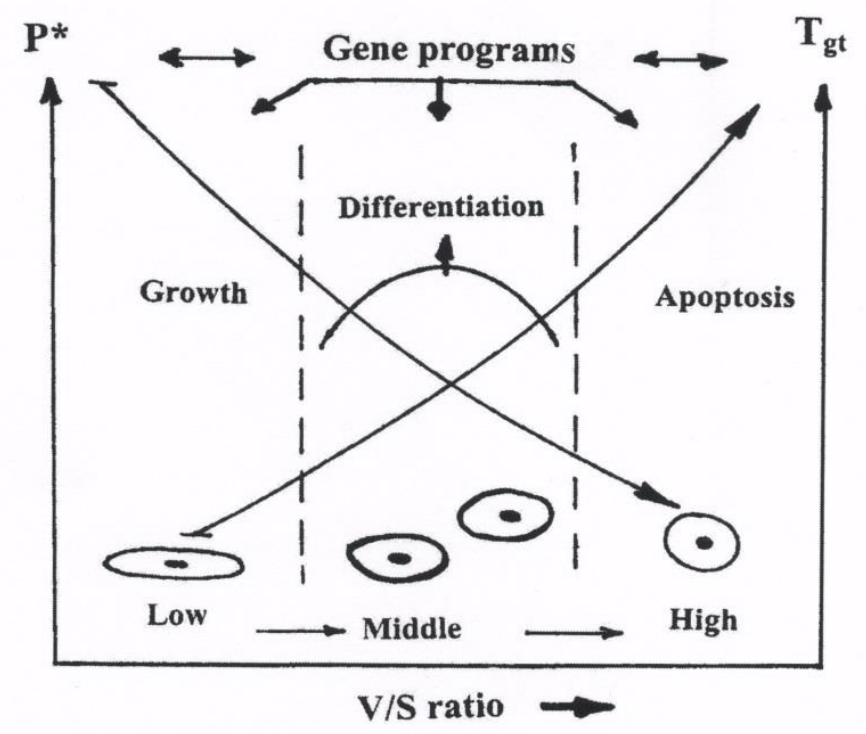

Figure 7. The scheme of switching of the gene programs from growth (at low volume to surface ratio) to differentiation (at middle volume to surface ratio), and to apoptosis (at high volume to surface ratio). 
Possibly, the change of volume to surface ratio leads to change of others cellular parameters connecting to bioelectric control of the cells, ion channel permeability and membrane voltage $(19,20,21)$. For example- for growing unicellular organisms Atanasov (22) has showed that the coefficient ' $\mathrm{a}_{\mathrm{vst}}$ ' and respectively membrane permeability coefficients $\left(\mathrm{P}_{\mathrm{K}+\mathrm{Na}}\right)$ for potassium $(\mathrm{K}+)$ and sodium $(\mathrm{Na}+)$ ions are directly connected to volume to surface ratio V/S ratio and mean generation time $\mathrm{T}_{\mathrm{gt}}$ of the cells:

$\mathrm{a}_{\mathrm{vst}}=\mathrm{P}_{\mathrm{K}+\mathrm{Na}+}=\mathrm{V} /\left(\mathrm{S} \cdot \mathrm{T}_{\mathrm{gt}}\right)$

Accordingly Eq.13 the manipulation of volume to surface ratio of the cells leads to changes of permeability coefficients for $\mathrm{K}+$ and $\mathrm{Na}+$ ions and to changes of membrane potential of the cells. As a result, the metabolic rate $\mathrm{P}^{*}$ and generation time of the cells change too. This reflects to the rate of the cell proliferation. The reorganization of cell cytoskeleton during change of the volume to surface ratio reflect to centrioles-nucleus signaling interactions (23, 24) and affects the gene programs to switch from growth to differentiation and apoptosis.

\section{REFERENCES}

1. Donachie, W.D. \& K.J. Begg, 1989. Cell length, nucleoid separation and cell division of rod-shaped and spherical cell of Escherichia coli. Journal of bacteriology, 171, 4633-4639.

2. Harvey, R.J., A.G. Marr \& P.R. Painter, 1967, Kinetics of growth of individual cell of Escherichia coli and Azotobacter agilis. Journal of bacteriology, 93, 605-617.

3. Ingber, D., 1999. How cells (might) sense microgravity. The FASEB journal, 13: S3S15.

4. Ingber, D. \& D.E. Folkman, 1989. Mechanochemical switching between growth and differentiation during fibroblast growth factor-stimulated angiogenesis in vitro: role of extracellular matrix. J. Cell Biol., 109, 317-330.

5. Folkman, J. \& A. Moskona, 1978. Role of cell shape in growth control. Nature, 273, 345-349.

6. Ingber, D.E. \& J.D. Jamieson, 1985. Cells as tensegrity structures: architectural regulation of histodifferentiation by physical forces tranduced over basement membrane. Andersson , L.C. Gahmberg, C.G.Ekblom, P.eds. Gene Expression During Normal and malignant Differentiation, 13-32 Academic Press Orlando, FL.

7. Kosłowski, J., M. Konarzewski \& A.T. Gawelczyk, 2003. Cell size as a link between noncoding DNA and metabolic rate scaling. PNAS , 100, 14080-14085.

8. Atanasov, A.T. \& V. Petrova-Tacheva, 2009. The allometric relationship between genome size (C-value) and total metabolic energy per lifespan, per unit body mass in animals. Medical Biology, 3, 1-10.

9. Nakaya, F., Y. Saito \& T. Motokawa, 2005. Experimental allometry:effect of size manipuplation rate of colonial ascidians. Proceedings of the Royal Society B, 272, 1963-1969.

10.Meyers, J., J. Craig \& D.J. Odde, 2006. Potential for control of signaling pathways via cell size and shape. Current Biology, 16, 1685-1693.

11.Atanasov, A.T., 2005. The linear alometric relationship between total metabolic energy per lifespan and body mass of poikilothermic animals. Biosystems, 82, 137-142.

12.Atanasov, A.T., 2007. The allometric relationships between gravitational constant, Max Planck constant and body mass, size, generation time density and speed of growth in prokaryotes. Trakia Journal of Sciences, 5, 19-29.

13.Atanasov, A.T., 2012. Scaling of biological space and time: volume to surface ratio in living organisms is proportional to lifespan. Trakia Journal of Sciences, 10 , 36-47.

14.Atanasov, A.T., 2012. Allometric scaling of total metabolic energy per lifespan in living organisms. Trakia Journal of Sciences, 10(3), 1-14.

15.Atanasov, A.T., 2014. Scaling of volume to surface ratio and doubling time in growing unicellular organisms: Do cells appear quantum-mechanical systems? In: INTERNATIONAL CONFERENCE OF COMPUTATIONAL METHODS IN SCIENCE AND ENGINEERING 2014 (ICCSME 2014), Vol. 1618 (1): 942-945. AIP PUBLISHING.

16.Rübner, M., 1908. Das Problem det Lebensdaur und seiner beziehunger sum Wachstum und Ernarnhung. Munchen: Oldenberg.

17.Holt, J.G., Bergey's Manual of Systemic Bacteriology $1^{\text {st }}$ ed.; (1984), vol.1:Gramnegative Bacteria of general medical or industrial importance; (1986), vol.3. Grampositive Bacteria other than Actinomyces; (1989):Archaeobacteria, Cyanobacteria and remaining Gram-negative bacteria; (1989) vol.4. Actynomicetes.

18.Lee, J.J., S.H. Hunter \& E.C. Bovee, 1985. Illustrated Guide to Protozoa, Lawrence, Kansa, USA. 
19.Blackiston, D.J., K.A. McLaughlin \& M. Levin, 2009. Bioelectric control of cell proliferation. Ion channels, membrane voltage and the cell cycle. Cell Cycle, 8(21), 3519-3528.

20.Jaffe, L.F., 1977. Electrical control of development. Ann. Rev. Biophys. Bioeng., 6,445-476.

21.Todorova, R.T., (2015). Structure-Function based Molecular Relationships in Ewing's Sarcoma. Biomed Research International, Vol. 2015, Article ID 798426.

22.Atanasov, A.T., 2013. Method for tentative evaluation of membrane permeability coefficient for sodium and potassium ions in unicellular organisms. Open Journal of Biophysics, 3(01), 91-98.

23.Atanasov, A.T., 2014. Possible role of centrioles as sensor center in cells. Trakia Journal of Sciences, 12, 74-78.

24.Atanasov, A.T., 2014. Are the centrioles sensory centres in living cells? Impact to mechanisms of cancer (a hypothesis). 9th International Conference of Anticancer Research, 6-10 October, Porto Carras, Sithonia, Greece. 